\title{
The characteristics of Salix viminalis L. crop flora established on soils with different phosphorus contents
}

\author{
Aneta Kutkowska ${ }^{1 *}$, Maria Janicka ${ }^{1}$, Jakub Paderewski ${ }^{2}$ \\ ${ }^{1}$ Warsaw University of Life Sciences - SGGW, Institute of Agriculture, Department of Agronomy, Nowoursynowska Str. 159, 02-776 Warsaw, \\ Poland \\ ${ }^{2}$ Warsaw University of Life Sciences - SGGW, Institute of Agriculture, Department of Biometry, Nowoursynowska Str. 159, 02-776 Warsaw, Poland \\ * M.Sc. A. Kutkowska, anetakutkowska@onet.pl, ORCID iD https://orcid.org/0000-0002-4417-5473 (Maria Janicka), https://orcid.org/0000-0003-3957- \\ 7467 (Jakub Paderewski)
}

Received: 02.06.2020

Accepted: 21.10.2020

Associated editor: J. Lasota

\section{Keywords}

Salix viminalis $\mathrm{L}$

Energy crops

Vascular flora

Dynamic of flora

Available phosphorous

\begin{abstract}
The aim of the study was determination of the effect of soil phosphorus content on the diversity and dynamics of flora accompanying energy willow (Salix viminalis L.) crops in two time periods. The study was carried out in 2013-2014 in 5-7 years old plantations and in 2018 in 10-11 years old plantations, in three locations of the Łódź voievodeship. Six plantations established in two groups of soils were evaluated: 1) with very low and low phosphorus content and 2) with medium and high phosphorus content. The vegetation accompanying willow was identified based on an analysis of 40 phytosociological relevés. The statistical analysis: PCA and cluster analysis were made. It was found that the vascular flora of Salix viminalis L. differed in the total number of species; 71 species were found in 5-7-year-old plantations, established on soils with a lower phosphorus contents, while on soils with a higher contents, the number of species was 56. In 10-11-year-old Salix viminalis L. crops the number of species was lower in two type of plantations. Perennial plants, dicotyledonous (74\%-83\%), hemicryptophytes, woodland and shrub, and meadow apophytes dominated in both plantation groups, irrespectively of the study period. Most species belonged to three phytosociological classes: Artemisietea vulgaris, Molinio-Arrhenatheretea, Stellarietea mediae. An analysis of the dynamics of flora, besides decreasing the number of species, showed that perennial species, woodland and shrub apophytes increased in both groups of the plantations. In crops on soils with a lower phosphorus content in the second part of the study period, species from the Artemisietea vulgaris class dominated, and on soils with a higher phosphorus content, species from the MolinioArrhenatheretea class. In both periods, legumes had a small share.
\end{abstract}

\section{Introduction}

Phosphorous is one of the important mineral nutrients necessary for the proper functioning of plants. Its availability to plants is determined by the soil phosphorus content and the soil-moisture conditions of the habitat, such as pH (Jurga and Filipek 2017), soil moisture (Spychalski et al., 2010; Ławniczak, 2011), organic matter and agricultural technology (Głowacka et al., 2017). In countries with intensive agriculture like: Belgium, Sweden, Netherlands over $50 \%$ of agriculture soils have phosphorous level above the recommended ranges (Ceulemans et al. 2014). Its excess causes negative changes in terrestrial and aquatic ecosystems (Sala et al. 2000). The content of this nutrient (P) in the soil determines the species richness of plant communities (Spychlaski et al., 2010, Ceulemans et al. 2014). It was found that, on soils with a phosphorus content-below $50-80 \mathrm{mg} \cdot \mathrm{kg}^{-1}$ (acetate + EDTA extraction), meadow communities were charac- terized by having the highest number of species (Janssens et al., 1998) and the highest share of species from the Fabaceae family (Spychalski et al., 2010). Therefore, environmental protection especially the biodiversity of plant communities, should be taken into account not only to reducing nitrogen pollution, but also to limited excess phosphorus from agricultural intensification (Ceulemans et al. 2014).

Salix $s p$. plantations used for energy purposes are established on soils with different nutrient contents, including phosphorus. In the literature, there are a few papers on the influence of soil phosphorus on vegetation accompanying particular crops. Most often they refer to meadow communities, but none in relation to Salix sp. crops. The aim of the study was to fill this gap and determine the effect of soil phosphorus content on the diversity of flora accompanying Salix viminalis L. crops. In addition, the dynamic of this vegetation was analyzed over two periods of the time (5-7 and 10-11 years after establishing the plantation). 


\section{Materials and methods}

The study of flora in six Salix viminalis L. plantations was carried out in 2013-2014 (in plantations 5-7 years old) and in 2018 (in plantations 10-11 years old), in three locations: Okołowice, Olsza and Świątniki (in Łódź voivodeship, central Poland) (Fig. 1).

\subsection{Soil conditions and plantation characteristics}

The Łódź region is characterised by a relatively flat surface. The dominating type of parent materials, as in all of Poland, are sands (62\%), clay (24\%) and silt (8\%) (Niewiadomski and Tołoczko, 2014). The study was carried out in six commercial Salix viminalis L. plantations. All plantations were located on the plain area. According to Polskie Towarzystwo Gleboznawcze (2009), the soil texture was classified as loamy sand (Okołowice 1), sandy loam (Okołowice 2, Olsza 3) and sand (Świątniki 4, Okołowice 5a and 5b). All studied soils contained very little clay fraction (Table 1). According to Polish Soil Classification 2019 (Systematyka Gleb Polski, 2019) and WRB Classification 2015 (IUSS Working Group WRB, 2015) they were Cambisols (3 plantations), Fluvisols (2 plantations) and Gleyic/Stagnic Phaeozems /Chernozems (1 plantation) which is hereinafter abbreviated as Phaeozems (Table 1).

Fluvisols are soils of the floodplain of the Ner river, formed from alluvial river sediments. Two Salix viminalis L. plantations established on Fluvisols (Okołowice 1 and 2) were located about $46 \mathrm{~m}$ and $200 \mathrm{~m}$ from the Ner river, which was separated by a flood embankment (Fig. 1). Whereas, plantation established on Phaeozems (Olsza 3) was located among arable land. Phaeozems were formed here as a result of drainage area and lowering of groundwater levels. The three other willow crops (Świątniki 4, Okołowice $5 \mathrm{a}$ and $5 \mathrm{~b}$ ) established on Cambisols were located near mixed forests. These soils are usually rich in nutrients for plants, with often defective water-air properties (Systematyka Gleb Polski, 2019).

Table 1

Characteristics of the soils on which the Salix viminalis L. plantations were established

\begin{tabular}{|c|c|c|c|c|c|c|c|c|c|}
\hline \multirow[t]{2}{*}{ No. } & \multirow[t]{2}{*}{ Location } & \multirow[t]{2}{*}{ Type of soil } & \multicolumn{5}{|c|}{ Percent of particle size of $\mathrm{mm}$ in diameter } & \multirow{2}{*}{$\begin{array}{l}\text { Soil } \\
\text { texture } \\
0-20 \mathrm{~cm}\end{array}$} & \multirow{2}{*}{$\begin{array}{l}\text { Soil } \\
\text { agriculture } \\
\text { complexes }\end{array}$} \\
\hline & & & $2.0-0.005 \mathrm{~mm}$ & $0.05-0.02 \mathrm{~mm}$ & $0.02-0.002 \mathrm{~mm}$ & $<0.002 \mathrm{~mm}$ & $<0.02 \mathrm{~mm}$ & & \\
\hline 1. & Okołowice & Fluvisols & 72.62 & 16.15 & 9.89 & 1.34 & 11.23 & loamy sand & $2 z$ \\
\hline 2. & Okołowice & Fluvisols & 59.44 & 23.03 & 15.09 & 2.44 & 17.53 & sandy loam & $2 z$ \\
\hline 3. & Olsza & Phaeozems & 60.23 & 22.40 & 15.10 & 2.27 & 17.37 & sandy loam & 9 \\
\hline 4. & Świątniki & Cambisols & 86.98 & 6.53 & 5.79 & 0.70 & 6.49 & sand & 7 \\
\hline $5 a$. & Okołowice & Cambisols & 93.33 & 3.64 & 3.03 & $<0.01$ & 3.03 & sand & 7 \\
\hline $5 b$. & Okołowice & Cambisols & 88.58 & 6.46 & 4.60 & 0.35 & 4.95 & sand & 6 \\
\hline
\end{tabular}

Fig. 1. Salix viminalis L. plantation established in Okołowice (1, 2, 5a, 5b), Olsza (3) and Świątniki (4)
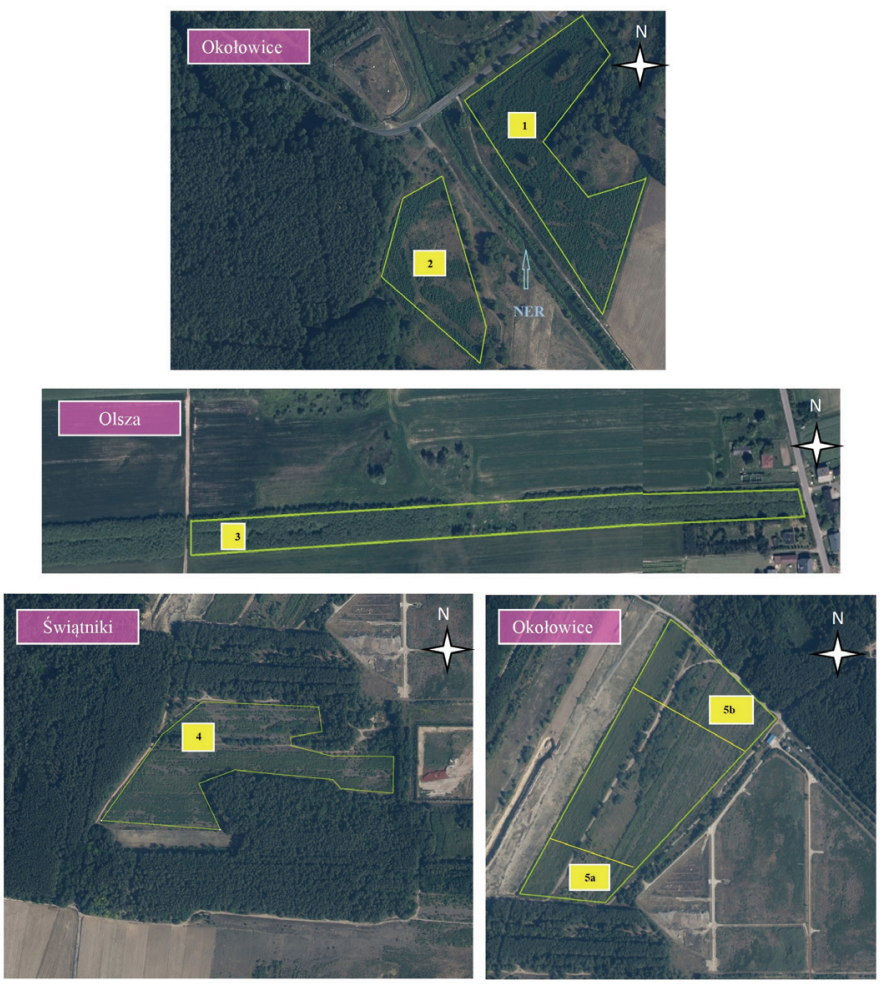
The studied Salix viminalis L. plantations were established on soils with different phosphorous contents: three plantations - on soils with very low and low phosphorous content (15.6-33.1 $\mathrm{mg} \cdot \mathrm{kg}^{-1}$ soil) and three plantations on soils with medium and high phosphorous content (53.1-81.9 $\mathrm{mg} \cdot \mathrm{kg}^{-1}$ soil ). All these soils were poor in potassium, but they had different contents of magnesium - from very low to high (Table 2). Soils of five plantations had a very acid and acid reaction and only of one plantation (on Phaeozems) had a neutral soil reaction. The content of organic matter in Fluvisols was quite high and ranged from 6.12-7.26\%, while in Phaeozems was $2.78 \%$ (Table 2). The higher content of organic matter in Fluvisols improves their structure and allows water to be retained in the soil longer. They are classified into soil agricultural complexes: $2 \mathrm{z}$ (medium quality grasslands) and 9 (soils less suitable for cereals and fodder crops). The water relations of $2 \mathrm{z}$ complex soils are not fully regulated, they are flooded, periodically dry or too wet. Whereas, the soils of complex 9 are too wet or too dry (Dobrzański and Zawadzki, 1981). Cambisols were characterized by the lowest content of organic matter from 1.88-2.28\% (Table 2). These are permeable soils, with poor water retention capacity, often too dry, and their moisture content is largely dependent on precipitation (Dobrzański and Zawadzki, 1981). Cambisols belong to the soil agricultural complexes: 6 (soils less suitable for rye, often too dry) and 7 (soils very bad for rye, very dry) (Table 1 ).

The information about the soil type and soil agriculture complex are based on agricultural maps on a scale of 1:5000 obtained from the Voivodeship Geodesy Office in Łódź (Solna St. 14, 91-423 Łódź, Poland), on the Łódź Voivodeship Geoportal (website 1) and Polish Soil Classification 2019 (Systematyka Gleb Polski, 2019). Soil samples were taken with an Egner Riehm's stick according to the methods for soil study material. Top soils analysis were car- ried out at the Regional Chemistry-Agriculture Station in Łódź and Warsaw. The content of available phosphorus and available potassium were determined according to the Egner-Riehm (DL) method - in the extract calcium lactate, magnesium according to Schatschabel method - in the extract calcium chloride. In addition, the soil $\mathrm{pH}$ in $\mathrm{KCl}$ and the content of organic matter according to the Tiurin method were identified. Soil texture according to PB 40 ed. 3, 14.02.2011 was also identified.

Before the energy willow plantations were established, the land was unused (fallow) for several years. Plantations were established by planting one-year-old willow sprouts (density 26.000 sprouts per ha). The study was carried out in 5-7 years old plantations (2013-2014) and later in 10-11 years old plantations (2018). During the study period, the plantations were not fertilized and no pesticides were used. The willow was harvested regularly - every 2-3 years (in the same year on all plantations).

\subsection{Weather conditions}

The weather conditions during the study were determined based on the dates recorded at the Meteorological Station of the Institute of Soil Science and Plant Cultivation, located in Bratoszewice, near Łódź. Long-term data were recorded for Łódź. In 2013, the sum of precipitation was about $40 \%$ higher than the long-term average. The sum of precipitation in the vegetation period was similar in 2014 and 2018 (402.4 and $421.7 \mathrm{~mm}$, respectively) and was slightly higher compared to the long-term mean (395.0 mm) (Table 3). Mean air temperatures between April and October in 2013 and 2014 were similar to each other and $0.8-1.2^{\circ} \mathrm{C}$ higher - than the long-term mean. In 2018 the mean temperature in growing season was $16.2^{\circ} \mathrm{C}$ and $2.9^{\circ} \mathrm{C}$ higher than the long-term mean (Table 3).

\section{Table 2}

Parameters of the soils on which Salix viminalis L. plantations were established

\begin{tabular}{|c|c|c|c|c|c|c|c|c|c|c|}
\hline \multirow[t]{2}{*}{ No. } & \multirow[t]{2}{*}{ Location } & \multirow[t]{2}{*}{$\mathrm{pH}$ in $\mathrm{KCl}$} & \multicolumn{6}{|c|}{ Contents in $\mathrm{mg} \cdot \mathrm{kg}^{-1}$ soil and their classification (plant available) } & \multicolumn{2}{|c|}{ Content of organic matter } \\
\hline & & & $\mathrm{P}$ & & $\mathrm{K}$ & & $\mathrm{Mg}$ & & $\%$ & C-org (\%) \\
\hline 1. & Okołowice & 4.3 & 15.6 & very low & 68.0 & low & 50.0 & medium & 6.12 & 3.55 \\
\hline 2. & Okołowice & 3.9 & 32.2 & low & 33.2 & very low & 51.0 & high & 7.26 & 4.21 \\
\hline 3. & Olsza & 6.9 & 33.1 & low & 49.8 & low & 13.0 & very low & 2.78 & 1.61 \\
\hline 4. & Świątniki & 4.3 & 53.1 & medium & 50.6 & low & 17.0 & low & 2.28 & 1.32 \\
\hline $5 a$. & Okołowice & 4.4 & 81.9 & high & 63.0 & low & 12.0 & very low & 1.97 & 1.14 \\
\hline $5 b$. & Okołowice & 4.3 & 55.3 & medium & 39.0 & very low & 11.0 & very low & 1.88 & 1.09 \\
\hline
\end{tabular}

Table 3

Weather conditions in the growing seasons in the years 2013-2014 and 2018 (Meteorological station in Bratoszewice)

\begin{tabular}{lll}
\hline Year & Average monthly air temperature IV-X $\left({ }^{\circ} \mathrm{C}\right)$ & Sums of monthly precipitation IV-X (mm) \\
\hline 2013 & 14.1 & 553.7 \\
2014 & 14.5 & 402.4 \\
2018 & 16.2 & 421.7 \\
$1971-2000$ & 13.3 & 395.0 \\
\hline
\end{tabular}




\subsection{Methods}

The vegetation accompanying willow (Salix viminalis L.) energy crops was identified based on an analysis of 40 phytosociological relevés i.e. ten relevés carried out in two types of plantations (established on Fluvisols and Phaeozems with very low and low contents of available $P$ and on Cambisols with medium and high contents of available $P$ in the soil) in each of the study periods (2013-2014, 2018). Relevés were performed according to the Braun-Blanquet (1964) method and each relevé represented an area of $100 \mathrm{~m}^{2}$. Subsequently, the number of each plant species was determined. The share of each plant species was determined based on the constancy class (S) and cover coefficient (D) calculated according to Pawłowski (1972). The Latin names of vascular plants were given according to Mirek et al. (2002), and phytosociological classifications according to Matuszkiewicz (2012). For each species, the following parameters were determined: geographical and historical groups, apophyte origin, biological stability, life-form, class, reproduction and status as an invasive. If the origin of an apophyte was not known, it was listed as "other". The geographical and historical groups, apophyte origins, biological stability and life-form class were identified based on the following sources: Anioł-Kwiatkowska (1974), Korniak (1992), Mirek et al. (2002), Rutkowski (2008), Sowa \& Warcholińska (1981), Szafer et al. (1969), Zając \& Zając (1975, 1992), Zając (1979). Invasive species status was determined based on Tokarska-Guzik et al. (2012). The reproduction of plants was identified according to Mowszowicz (1986).

\subsection{Statistical analysis}

It was calculated the total coverage of the species with the same life-form, class, reproduction, geographical and historical groups, apophytes origin and biological stability (the set of variables) in two levels of phosphorous content in the two studied period (these four combinations form four values for the above variables). This data set was standardized for variables and an- alyzed by the principal component analysis (PCA). It allows to specify the conditions that were favorable to species characterized by considered features (variables). Also the cluster analysis was done for this standardized data set in the aim to group the strongly connected variables. During this analysis it was used euclidean distance and Ward method. The aim was to group the features of species that often co-exist under given conditions. These two analyses, PCA and cluster analysis, are complementary. The PCA analysis was made with the use of R software (R Core Team (2019) (website 2) according proposal made by Sienkiewicz-Paderewska and Paderewski (2015). The Cluster analysis was done with the use of hclust function contained in the stats package in the R software.

\section{Results}

The vascular flora of energy willow (Salix viminalis L.) crops, established on soils with different phosphorus contents, differed in the total number of species (Table 4, 5). In the first period of study, on soils with low contents of available $\mathrm{P}$, from 24 species on Fluvisols (Okołowice 2) to 40 species on Phaeozems (Olsza 3) were noted (Table 4). On soils with medium and high contents of available P (Cambisols), the number of species ranged from 27-39. In total 71 species were found in 5-7-year-old plantations, established on soils with very low and low phosphorus contents, while on soils with medium and high phosphorus contents, the number of species was $20 \%$ lower (56 species) (Table 4). Irrespectively of the content of phosphorous in soils, the average number of species in the phytosociological relevé was similar and amounted to 20 or less (Table 6). In 2018, in 10-11-year-old Salix viminalis L. crops, the number of species was lower than in 2013-2014 years and ranged from 18 on Phaeozems with low contents of available P (Olsza, 3) to 29 on Cambisols with medium contents of available $\mathrm{P}$ (Okołowice, $5 \mathrm{~b}$ ) (Table 5 ). In this period of the study, differentiation of the number of species depending on the soil phosphorous content was lower: 35 (low content) and 42 (high content) (Table 4).

Table 4

Species occurred in Salix viminalis L. plantations in 2013-2014

\begin{tabular}{|c|c|c|c|c|c|c|c|c|c|c|c|c|c|}
\hline \multirow[t]{4}{*}{ Name of species } & \multicolumn{6}{|c|}{ Number of plantation } & \multirow[t]{4}{*}{ Name of species } & \multicolumn{6}{|c|}{ Number of plantation } \\
\hline & 1 & 2 & 3 & 4 & $5 a$ & $5 \mathrm{~b}$ & & 1 & 2 & 3 & 4 & $5 a$ & $5 b$ \\
\hline & \multicolumn{6}{|c|}{ Type of soil } & & \multicolumn{6}{|c|}{ Type of soil } \\
\hline & a & a & $\mathrm{b}$ & c & c & c & & a & $\mathrm{a}$ & $\mathrm{b}$ & c & c & c \\
\hline Acer platanoides $\mathrm{L}$. & & & $+*$ & & & & Echinocystis lobata (F. Michx.) Torr. \& A. Gray & & & + & & & \\
\hline Achillea millefolium L. s. str. & + & & & + & + & + & Elymus repens (L.) Gould & + & + & + & & + & + \\
\hline Agrostemma githago L. & & & + & & & & Epilobium roseum Schreb. & & & + & & + & \\
\hline Agrostis capillaris L. & & & + & + & + & + & Equisetum arvense L. & & & & & + & + \\
\hline Agrostis gigantea Roth & & & & & + & & Erigeron annuus (L.) Pers. & & & & + & + & \\
\hline Alisma plantago-aquatica $\mathrm{L}$. & & + & & & & & Fallopia convolvulus (L.) Á. Löve & + & + & & & & \\
\hline Anchusa arvensis (L.) M. Bieb. & & & & & + & & Frangula alnus Mill. & & + & + & & & \\
\hline Anthoxanthum odoratum L. & & & & & & + & Galeopsis bifida Boenn. & + & + & & & & \\
\hline
\end{tabular}


Table 4 - cont.

\begin{tabular}{|c|c|c|c|c|c|c|c|c|c|c|c|c|c|}
\hline \multirow[t]{4}{*}{ Name of species } & \multicolumn{6}{|c|}{ Number of plantation } & \multirow[t]{4}{*}{ Name of species } & \multicolumn{6}{|c|}{ Number of plantation } \\
\hline & 1 & 2 & 3 & 4 & $5 a$ & $5 b$ & & 1 & 2 & 3 & 4 & $5 a$ & $5 b$ \\
\hline & \multicolumn{6}{|c|}{ Type of soil } & & \multicolumn{6}{|c|}{ Type of soil } \\
\hline & $\mathrm{a}$ & a & $\mathrm{b}$ & c & $\mathrm{c}$ & $\mathrm{c}$ & & $\mathrm{a}$ & $\mathrm{a}$ & $\mathrm{b}$ & c & c & $\mathrm{C}$ \\
\hline Apera spica-venti (L.) P. Beauv. & & & + & & & & Galeopsis tetrahit L. & + & & & & + & \\
\hline Arenaria serpyllifolia L. & & & & & + & & Galinsoga ciliata (Raf.) S. f. Blake & & & + & & & \\
\hline Artemisia campestris $\mathrm{L}$. & & & & & & + & Galinsoga parviflora Cav. & & + & & & & \\
\hline Artemisia vulgaris $\mathrm{L}$. & + & & + & + & + & + & Galium aparine $\mathrm{L}$. & + & + & + & & & \\
\hline Betula pendula Roth & & & & + & & & Geum urbanum L. & + & + & + & & & \\
\hline Betula pubescens Ehrh. & & & & + & & & Glechoma hederacea L. & + & + & & & & \\
\hline Bromus hordeaceus L. & & & & + & & & Gnaphalium sylvaticum L. & & & & & + & \\
\hline Calamagrostis epigejos (L.) Roth & + & + & & + & + & + & Helichrysum arenarium (L.) Moench & & & & & + & \\
\hline Calystegia sepium (L.) R.Br & + & & & & & & Hieracium pilosella $\mathrm{L}$. & & & & + & + & + \\
\hline Capsella bursa-pastoris (L.) Medik. & + & & & & & & Holcus lanatus L. & + & & + & & + & + \\
\hline Carduus acanthoides L. & + & & + & & & & Humulus lupulus L. & & + & & & & \\
\hline Centaurea jacea L. & & & & + & & & Hypericum perforatum $\mathrm{L}$. & & & + & + & & + \\
\hline Chelidonium majus L. & + & & & & & & Hypochoeris radicata $\mathrm{L}$. & & & & & + & \\
\hline Cirsium arvense (L.) Scop. & + & + & & & & & Jasione montana L. & & & & & + & + \\
\hline Conium maculatum $\mathrm{L}$. & + & & & & & & Juncus effusus L. & & + & & & & \\
\hline Convolvulus arvensis $\mathrm{L}$. & & & + & + & + & & Lactuca serriola L. & + & & + & & & \\
\hline Conyza canadensis (L.) Cronquist & & + & + & & + & + & Leontodon autumnalis L. & & & + & & & + \\
\hline Crepis biennis $\mathrm{L}$. & & & + & & & + & Lythrum salicaria L. & & + & & & & \\
\hline Dactylis glomerata L. & & & + & & & + & Matricaria maritima subsp. inodora (L.) Dostál & + & & & & & \\
\hline Daucus carota L. & & & & + & + & + & Melandrium album (Mill.) Gracke & + & + & & & + & \\
\hline Deschampsia caespitosa (L.) P. Beauv. & + & + & & & & & Melilotus alba Medik. & & & & + & & \\
\hline Myosotis arvensis (L.) Hill & & & + & + & & + & Setaria viridis (L.) P. Beauv. & & & & & + & \\
\hline Oenothera biennis L. & & & & + & + & + & Solidago canadensis L. & + & & + & + & + & \\
\hline Padus serotina (Ehrh.) Borkh. & + & & & + & + & + & Solidago gigantea Aiton & & & + & & & \\
\hline Phleum pretense L. & & & + & & + & & Sonchus arvensis $L$. & & & + & & & \\
\hline Pinus sylvestris L. & & & & + & + & + & Sorbus aucuparia L. emend. Hedl. & & & & & & + \\
\hline Plantago major L. & + & & + & & & & Stachys palustris L. & + & & & & & \\
\hline Poa annua L. & & + & & & & & Stellaria graminea L. & & & + & & & \\
\hline Poa pratensis L. & + & + & + & & & + & Stellaria holostea L. & & + & & & & \\
\hline Polygonum lapathifolium L. & + & + & & & & & Stellaria media (L.) Vill. & + & & + & & & \\
\hline Polygonum minus Huds. & & + & & & & & Tanacetum vulgare $\mathrm{L}$. & + & & & + & + & + \\
\hline Potentilla supina $\mathrm{L}$. & + & & & & & & Taraxacum officinale F.H. Wigg. & & & + & + & + & + \\
\hline Prunella vulgaris $\mathrm{L}$. & & & + & & & & Thlaspi arvense L. & & & & & & + \\
\hline Quercus petraea (Matt.) Liebl. & & & + & & & & Tragopogon pratensis L. & & & + & & & \\
\hline Quercus robur L. & & & & + & + & + & Trifolium arvense $\mathrm{L}$. & & & + & + & + & + \\
\hline Ranunculus repens L. & & + & & & & & Urtica dioica $\mathrm{L}$. & + & + & & & & \\
\hline Rosa canina $\mathrm{L}$. & & & + & & & & Verbascum densiflorum Bertol. & & & & & + & \\
\hline Rubus caesius L. & + & & + & & & & Vicia angustifolia L. & & & & & + & \\
\hline Rumex acetosa L. & + & & & & & + & Vicia cracca L. & & & & + & & + \\
\hline Rumex acetosella L. & & & & + & + & + & Vicia hirsuta (L.) Gray & & & + & + & + & + \\
\hline Rumex obtusifolius L. & + & & & & & & Vicia villosa Roth & & & + & & + & \\
\hline Sambucus nigra L. & + & & + & & & & Viola arvensis Murray & & & & & + & + \\
\hline Senecio jacobaea L. & & & & + & + & + & Total number & 35 & 24 & 40 & 27 & 39 & 34 \\
\hline
\end{tabular}

$*+$ means that the species was present, empty cell - no species

Type of soil: a - Fluvisols (low and very low contents of P), b - Phaeozems (low contents of P),

c-Cambisols (medium and high contents of P) Number of plantations: 1, 2, 5a, 5b - Okołowice; 3 - Olsza; 4 -Świątniki 
Table 5

Species occurred in individual Salix viminalis L. plantations in 2018

\begin{tabular}{|c|c|c|c|c|c|c|c|c|c|c|c|c|c|}
\hline \multirow[t]{4}{*}{ Name of species } & \multicolumn{6}{|c|}{ Number of plantation } & \multirow[t]{4}{*}{ Name of species } & \multicolumn{6}{|c|}{ Number of plantation } \\
\hline & 1 & 2 & 3 & 4 & $5 a$ & $5 b$ & & 1 & 2 & 3 & 4 & $5 a$ & $5 \mathrm{~b}$ \\
\hline & \multicolumn{6}{|c|}{ Type of soil } & & \multicolumn{6}{|c|}{ Type of soil } \\
\hline & $\mathrm{a}$ & $\mathrm{a}$ & $\mathrm{b}$ & $\mathrm{c}$ & $\mathrm{c}$ & $\mathrm{c}$ & & $\mathrm{a}$ & $\mathrm{a}$ & $\mathrm{b}$ & $\mathrm{c}$ & $\mathrm{c}$ & $\mathrm{c}$ \\
\hline Acer platanoides L. & & & & $+*$ & & & Hypochoeris radicata $\mathrm{L}$. & & & & + & & \\
\hline Achillea millefolium L. s. str. & & & & + & + & + & Jasione montana L. & & & & + & & + \\
\hline Agrostis capillaris L. & + & & & + & + & & Leontodon autumnalis L. & & & & & & + \\
\hline Agrostis gigantea Roth & & + & & & + & & Leonurus cardiaca L. & + & & & & & \\
\hline Anthoxanthum aristatum Boiss. & & & & & & + & Oenothera biennis L. & & & & + & + & + \\
\hline Arctium minus (Hill) Bernh. & + & + & & & & & Padus avium Mill. & + & + & & & & \\
\hline Artemisia vulgaris L. & & + & + & & + & + & Padus serotina (Ehrh.) Borkh. & & + & & + & + & + \\
\hline Berteroa incana (L.) DC. & & & & & + & + & Phragmites australis (Cav.) Trin. ex Steud. & + & & & & & \\
\hline Betula pendula Roth & & & & + & + & + & Pinus sylvestris L. & & & & + & + & + \\
\hline Calamagrostis epigejos (L.) Roth & + & + & & & + & + & Plantago media L. & & & & & + & \\
\hline Carduus acanthoides L. & & & + & & & & Poa pratensis $\mathrm{L}$. & + & + & & & & \\
\hline Chelidonium majus L. & + & + & & & & & Quercus petraea (Matt.) Liebl. & & & + & & & + \\
\hline Chenopodium album L. & & & & + & & & Quercus robur L. & & & & + & + & \\
\hline Cirsium arvense (L.) Scop. & + & + & + & & & & Rubus caesius L. & + & + & + & & & \\
\hline Convolvulus arvensis L. & & + & + & + & & & Rumex acetosa $\mathrm{L}$. & & & & + & + & + \\
\hline Conyza canadensis (L.) Cronquist & & & & + & & & Rumex acetosella L. & & & & + & + & + \\
\hline Dactylis glomerata L. & & & + & & & + & Sambucus nigra L. & + & + & + & & & \\
\hline Daucus carota L. & & & & + & + & + & Senecio jacobaea L. & & & & + & + & + \\
\hline Elymus repens (L.) Gould & + & + & + & & + & + & Solidago canadensis L. & + & + & + & + & + & + \\
\hline Epilobium roseum Schreb. & & & + & & & & Solidago gigantea Aiton & + & & & & & \\
\hline Equisetum arvense L. & & & + & & & + & Stellaria media (L.) Vill. & + & + & + & & & \\
\hline Erigeron annuus (L.) Pers. & + & & & + & & + & Tanacetum vulgare L. & & & & + & + & + \\
\hline Euonymus europea L. & & + & & & & & Taraxacum officinale F.H. Wigg. & & & & + & + & + \\
\hline Fallopia convolvulus (L.) Á. Löve & + & & & & & & Thlaspi arvense L. & & & & + & & \\
\hline Galeopsis bifida Boenn. & & + & & & & & Torilis japonica (Houtt.) DC. & & & + & & & \\
\hline Geum urbanum L. & + & & + & & & & Trifolium arvense L. & & & & & + & \\
\hline Glechoma hederacea L. & + & + & & & & & Urtica dioica $\mathrm{L}$. & + & + & + & & & \\
\hline Gnaphalium sylvaticum L. & & & & & & + & Vicia cracca L. & & & & + & & \\
\hline Helichrysum arenarium (L.) Moench & & & & & + & & Vicia hirsuta (L.) Gray & & & + & & & + \\
\hline Hieracium pilosella $\mathrm{L}$. & & & & + & + & + & Viola arvensis Murray & & & & & + & + \\
\hline Holcus lanatus L. & & + & & + & + & + & Total number & 20 & 20 & 18 & 26 & 25 & 29 \\
\hline Hypericum perforatum L. & & & + & + & & + & & & & & & & \\
\hline
\end{tabular}

* + means that the species was present, empty cell - no species

Type of soil: a - Fluvisols (low and very low contents of P), b- Phaeozems (low contents of P), c-Cambisols (medium and high contents of P) Number of plantations: 1, 2, 5a, 5b - Okołowice; 3 - Olsza; 4 - Świątniki

Perennial plants, dicotyledonous, hemicryptophytes, woodland and shrub, and meadow apophytes dominated in all plantations irrespectively of type of soil and contents of available $\mathrm{P}$ (Table 6). In the total number of species found in all plantations in both study periods, $74-83 \%$ were dicotyledonous taxa, while 60-81\% were perennial species (Table 6).
On Cambisols with a higher phosphorous content, more (by approx. 22.5 percentage points than on Fluvisols and by approx. 17 percentage points than on Phaeozems) sandyside and xerothermic grasslands apophytes were recorded (e.g. Oenothera biennis L., Rumex acetosella L., Verbascum densiflorum Bertol.) mean in both periods of the study. Whereas, on Fluvisols and 
Table 6

Characteristics of flora of Salix viminalis L. on Fluvisols, Phaeozems and Cambisols with different available P contents, in the years 2013-2014 and 2018

\begin{tabular}{|c|c|c|c|c|c|c|c|}
\hline \multirow[t]{3}{*}{ Category } & & \multicolumn{6}{|c|}{ Type of soil and content of available $\mathrm{P}$} \\
\hline & & \multicolumn{2}{|c|}{ Fluvisols $A^{*}$} & \multicolumn{2}{|c|}{ Phaeozems A } & \multicolumn{2}{|c|}{ Cambisols B } \\
\hline & & 2013-2014 & 2018 & 2013-2014 & 2018 & 2013-2014 & 2018 \\
\hline \multirow{2}{*}{$\begin{array}{l}\text { Geographical and } \\
\text { historical groups (\%) }\end{array}$} & Antropophytes & 21.7 & 22.2 & 30.0 & 16.7 & 21.4 & 19.0 \\
\hline & Apophytes & 78.3 & 77.8 & 70.0 & 83.3 & 78.6 & 81.0 \\
\hline \multirow[t]{6}{*}{ Apophytes origin (\%) } & Meadow species & 30.6 & 23.8 & 46.4 & 26.7 & 45.5 & 41.2 \\
\hline & Woodland and shrub species & 52.8 & 57.1 & 25.7 & 53.3 & 25.0 & 29,4 \\
\hline & Xerothermic grasslands & 0.0 & 4.8 & 3.6 & 6.7 & 9.1 & 5.9 \\
\hline & Waterside and wetside & 11.1 & 9.5 & 10.7 & 13.3 & 4.5 & 5.9 \\
\hline & Sandyside & 0.0 & 0.0 & 3.6 & 0.0 & 15.9 & 17.6 \\
\hline & Other & 5.5 & 4.8 & 0.0 & 0.0 & 0.0 & 0.0 \\
\hline \multirow[t]{3}{*}{ Biological stability (\%) } & Perennial species & 60.0 & 81.4 & 60.0 & 77.8 & 60.7 & 69 \\
\hline & Short-lived species & 32.6 & 14.8 & 37.5 & 22.2 & 33.9 & 23.8 \\
\hline & Short-lived species- perennial species & 6.5 & 3.8 & 2.5 & 0.0 & 5.4 & 7.2 \\
\hline \multirow[t]{8}{*}{ Life-form (\%) } & Hemicryptophyte & 43.5 & 48.2 & 52.5 & 44.5 & 53.6 & 54.8 \\
\hline & Therophyte & 30.4 & 11.1 & 27.5 & 16.6 & 25.0 & 19.0 \\
\hline & Geophyte & 10.8 & 18.5 & 2.5 & 16.6 & 7.1 & 9.5 \\
\hline & Herbaceous Chamaephyte & 2.2 & 3.7 & 2.5 & 5.6 & 1.8 & 2.4 \\
\hline & Woody chamaephyte & 2.2 & 0.0 & 0.0 & 0.0 & 1.8 & 0.0 \\
\hline & Nanophanerophyte & 6.5 & 11.1 & 10.0 & 11.1 & 0.0 & 0.0 \\
\hline & Megaphanerophyte & 2.2 & 3.7 & 5.0 & 5.6 & 10.7 & 14.3 \\
\hline & Hydrophyte and Helophyte & 2.2 & 3.7 & 0.0 & 0.0 & 0.0 & 0.0 \\
\hline \multirow[t]{4}{*}{ Class (\%) } & Dicotyledones & 82.6 & 74.0 & 82.5 & 83.3 & 76.8 & 78.6 \\
\hline & Equisetaceae & 0.0 & 0.0 & 0.0 & 5.6 & 1.8 & 2.4 \\
\hline & Monocotyledones & 17.4 & 26.0 & 17.5 & 11.1 & 19.6 & 16.6 \\
\hline & Pinopsida & 0.0 & 0.0 & 0.0 & 0.0 & 1.8 & 2.4 \\
\hline \multirow[t]{2}{*}{ Reproduction (\%) } & seed & 50.0 & 37.0 & 47.5 & 27.8 & 57.2 & 56 \\
\hline & seed and vegetative & 50.0 & 63.0 & 52.5 & 72.2 & 42.8 & 44 \\
\hline \multicolumn{2}{|c|}{ Mean number of species in relevé } & 13.9 & 9.7 & 20.7 & 10.3 & 16.4 & 14.6 \\
\hline \multicolumn{2}{|l|}{ Number of species } & 46 & 27 & 40 & 18 & 56 & 42 \\
\hline
\end{tabular}

A - low and very low contents of $\mathrm{P}, \mathrm{B}$ - medium and high contents of $\mathrm{P}$

Phaeozems, soils with a lower phosphorous content, more (by approx. 50\%) waterside and wetside apophytes were found (e.g. Alisma plantago aquatica L., Phragmites australis (Cav.) Trin. Ex Steud) (Table 6). Differences in the proportion of apophytes of sandyside, xerothermic grasslands and waterside, wetside in plantations were related to the plant soil preferences, soil texture and especially to the soil moisture. On well-drained sandy Cambisols with a higher phosphorous content, very acidic reaction and low humidity occurred sandyside and xerothermic grasslands apophytes e.g. Arenaria serpyllifolia L., Artemisia campestris L., Jasione montana L. Species like: Anthoxanthum aristatum Boiss oraz Agrostis capillaris L. were noted on dry Cambisols. Stellaria media (L.) Vill. was occured on Phaeozems as well as on Fluvisols. This species preferred moist and fertile habitats. Whereas, more moist Fluvisols periodically or constantly too wet or too dry (with a lower phosphorous content) favored the occurrence of waterside and wetside apophytes e.g. Alisma plantago aquatica L., Phragmites australis (Cav.) Trin. Ex Steud. (Table 6).

It was found that the presence of species in willow energy plantations also resulted from the location of the plantations in the landscape. Occurrence of annual species like: Apera spica-venti (L.) P.Beauv., Galinsoga ciliata (Raf.) S.F. Blake and Agrostemma githago L. were favored by the location of energy willow crops among arable land (low phosphorus content). The highest number of megafanerophytes in both study periods was recorded on Cambisols (medium and high phosphorus content) 
in the vicinity of forests (3-5 species), e.g. Betula pendula Roth, Betula pubescens Ehrh., Quercus robur L. Whereas, hydrophyte, helophyte (1 species - Alisma plantago aquatica L.) was found only on Fluvisols near the Ner river. The location of perennial Salix viminalis L. crops (5-11 years old) had little effect on other life-forms, woodland and shrub apophytes, meadow apophytes, geographical and historical groups and biological stability. This was the result of willow cultivation technology and its many years of use.

Most species belonged to the phytosociological classes: $\mathrm{Ar}$ temisietea vulgaris (ruderal communities) - characteristic for perennial and climber plants occurring in ruderal habitats and on the banks of water reservoirs, Molinio-Arrhenatheretea characteristic for grassland communities of the temperate zone and Stellarietea mediae - characteristic for arable land (Fig. 2). In crops on soils with a lower phosphorus content in the second part of the study period, species from the Artemisietea vulgaris class (40\%) dominated, while on soils with a higher phosphorus content, species from the Molinio-Arrhenatheretea class (19.1\%). In this period, sporadic species not classified to any phytosociological classes had a high share (Fig. 2).

Among the species belonging to grasses and other dicotyledonous plants, species with a greater cover coefficient on Cambisols (very acidic, well-drained and rather dry soils) occurred: Agrostis capillaris L. (D = 2276 in the first study period, D = 1700 in the second study period), Calamagrostis epigejos (L.) Roth, ( $\mathrm{D}=452$ in the first study period, $\mathrm{D}=2075$ in the second study period), Hieracium pilosella $\mathrm{L}$. ( $\mathrm{D}=850$ in the first study period, $\mathrm{D}=375$ in the second study period) and Achillea millefolium L. s. str. ( $\mathrm{D}=877$ in the first study period, $\mathrm{D}=500$ in the second study period) (Table 7). However, on Fluvisols and Phaeozems (loamy sand and sandy loam soils) a greater cover coefficient in both periods, the following species were recorded: Urtica dioica L. (D $=1625$ in the first study period, D = 2400 in the second study period) and Calamagrostis epigejos (L.) Roth ( $\mathrm{D}=800$ in the first period, D = 326 in the second study period) (Table 7). Agrostis capillaris L. and Hieracium pilosella L. are the species typical of light sandy acidic, well-drained and rather dry soils on which plantations were established (Table 1). Achillea millefolium L. s. str. and Calamagrostis epigejos (L.) Roth are the species with a large range of occurrence. Besides Calamagrostis epigejos (L.). Roth is an expansive grass of poor, acid soil and sandy habitats. It tolerates moderate shading and is very expansive in forest clearing and nurseries. This species increased its cover coefficient in Salix viminalis L. crops over time. Similarly Urtica dioica L., which is common in shrubs and ruderal sites.

An analysis of the dynamics of the flora showed a decrease in the total number of species with the age of the plantation. In all plantations, mainly the number of short-lived species decreased, which in 2018 ranged from 3 to 7. The number of species decreased more in crops on Fluvisols and Phaeozems (by half), while in crops on Cambisols, the number of species in 2018 was lower by $25 \%$ (Table 4, 5 ). In addition, perennial species, woodland and shrub apophytes increased in all plantations irrespectively of the type of soil and content of available P (Table 6). The number of meadow apophytes in the first study period in individual plantations ranged from 6 to 14 and decreased (except for plantation 4, in which 9 species were recorded in 2018, i.e. 1 more than in the first period of the study) with plantation age to 3-9. Among the meadow apophytes, Daucus carota L., occurred only in three plantations established on Cambisols in both study periods (Table 4,5). These soils also favored the occurrence of Anthoxanthum odoratum L., Anthoxanthum aristatum Boiss. and Agrostis capillaris L. Whereas, species characteristic for cereal crops like: Apera spica-venti (L.) P.Beauv, Galinsoga ciliata (Raf.) S.F. Blake and rare species-Agrostemma githago L. were noted only in plantation located near arable fields, on Phaeozems (Table 4). These short-lived species occurred only in the first study period (Table 4).

Among trees and shrubs, Rubus caesius L. and Padus serotina (Ehrh.) Borkh. the cover coefficient increased (Rubus caesius L. from D $=101$ to $\mathrm{D}=452$ on soils with lower P, Padus serotina (Ehrh.) Borkh. from D=156 to D=1125 on soils with higher P) (Table 7).
Fig. 2. Share of phytosociological classes in two study periods (\%)

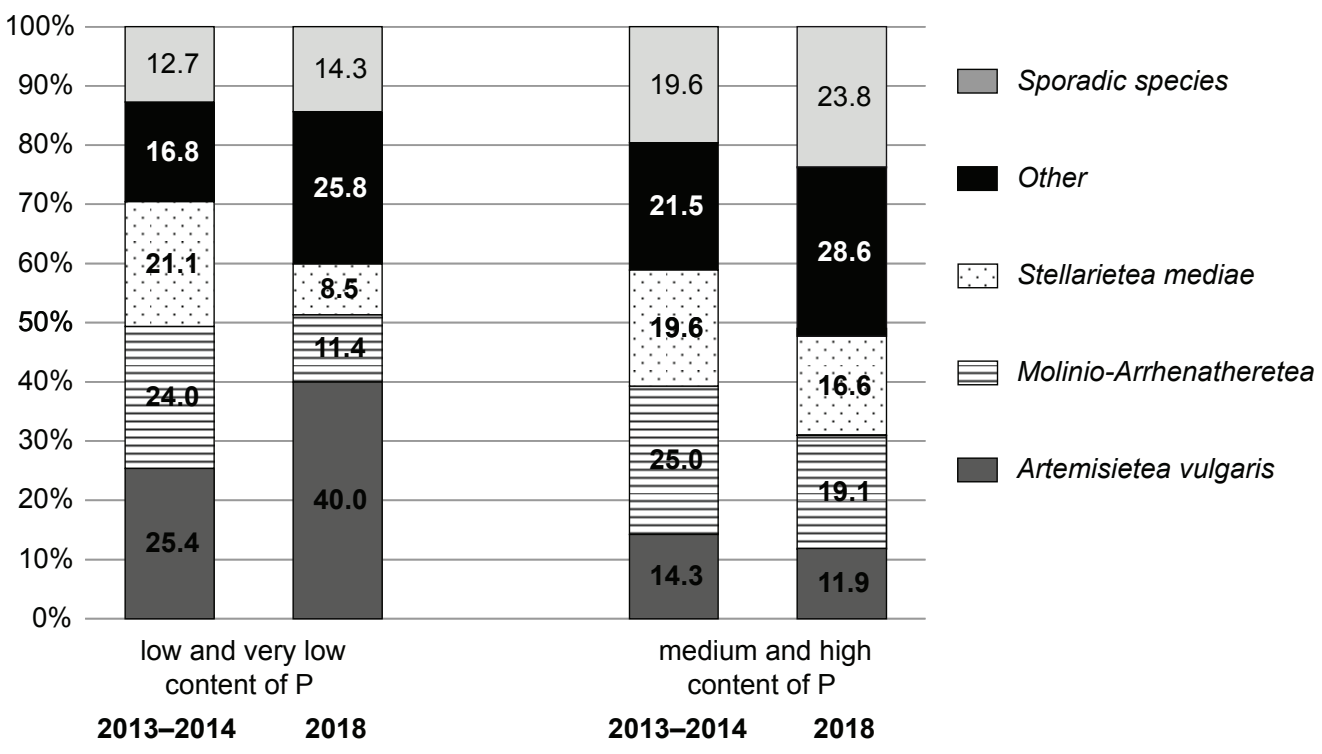


Table 7

Species with the constancy classes III-V (S) and cover coefficient (D) on soils with different contents of available P, in the years $2013-2014$ and 2018

\begin{tabular}{|c|c|c|c|c|c|c|c|c|}
\hline \multirow[t]{4}{*}{ Name of species } & \multicolumn{8}{|c|}{ Type of soil and content of available P } \\
\hline & \multicolumn{4}{|c|}{ Fluvisols and Phaeozems A* } & \multicolumn{4}{|l|}{ Cambisols B } \\
\hline & 2013-2014 & 2013-2014 & 2018 & 2018 & 2013-2014 & 2013-2014 & 2018 & 2018 \\
\hline & $\mathrm{S}$ & $\mathrm{D}$ & $\mathrm{S}$ & $\mathrm{D}$ & $\mathrm{S}$ & $\mathrm{D}$ & S & $\mathrm{D}$ \\
\hline Achillea millefolium L. s. str. & I & 1 & 0 & 0 & IV & 877 & III & 550 \\
\hline Agrostis capillaris L. & I & 50 & I & 50 & IV & 2276 & IV & 1700 \\
\hline Artemisia vulgaris L. & III & 376 & II & 3 & III & 103 & III & 5 \\
\hline Betula pendula Roth & 0 & 0 & 0 & 0 & I & 1 & IV & 301 \\
\hline Calamagrostis epigejos (L.) Roth & III & 800 & III & 326 & III & 452 & IV & 2075 \\
\hline Carduus acanthoides L. & III & 151 & I & 1 & 0 & 0 & 0 & 0 \\
\hline Cirsium arvense (L.) Scop. & III & 201 & II & 102 & 0 & 0 & 0 & 0 \\
\hline Elymus repens (L.) Gould & III & 300 & IV & 475 & II & 325 & II & 275 \\
\hline Galium aparine $\mathrm{L}$. & IV & 650 & 0 & 0 & 0 & 0 & 0 & 0 \\
\hline Geum urbanum L. & III & 201 & II & 200 & 0 & 0 & 0 & 0 \\
\hline Glechoma hederacea L.. & II & 351 & III & 1150 & 0 & 0 & 0 & 0 \\
\hline Hieracium pilosella L. & 0 & 0 & 0 & 0 & IV & 850 & III & 375 \\
\hline Holcus lanatus L. & III & 375 & I & 100 & II & 450 & III & 153 \\
\hline Oenothera biennis L. & 0 & 0 & 0 & 0 & IV & 253 & IV & 252 \\
\hline Padus serotina (Ehrh.) Borkh. & 0 & 0 & 0 & 0 & $\mathrm{~V}$ & 156 & $\mathrm{~V}$ & 1125 \\
\hline Pinus sylvestris L. & 0 & 0 & 0 & 0 & III & 104 & III & 376 \\
\hline Poa pratensis L. & III & 625 & II & 325 & $\mathrm{I}$ & 175 & 0 & 0 \\
\hline Quercus robur L. & 0 & 0 & 0 & 0 & IV & 3 & II & 101 \\
\hline Rubus caesius L. & II & 101 & III & 452 & 0 & 0 & 0 & 0 \\
\hline Rumex acetosella L. & 0 & 0 & 0 & 0 & III & 103 & III & 202 \\
\hline Senecio jacobaea L. & 0 & 0 & 0 & 0 & II & 1 & III & 152 \\
\hline Solidago canadensis L. & II & 150 & III & 928 & III & 326 & IV & 427 \\
\hline Stellaria media (L.) Vill. & 0 & 0 & IV & 350 & 0 & 0 & 0 & 0 \\
\hline Tanacetum vulgare L. & I & 51 & 0 & 0 & III & 103 & IV & 203 \\
\hline Trifolium arvense $\mathrm{L}$. & I & 50 & 0 & 0 & IV & 377 & I & 1 \\
\hline Urtica dioica $\mathrm{L}$. & IV & 1625 & IV & 2400 & 0 & 0 & 0 & 0 \\
\hline Vicia hirsuta (L.) Gray & I & 50 & I & 1 & III & 152 & I & 1 \\
\hline
\end{tabular}

A - low and very low contents of P, B - medium and high contents of $\mathrm{P}$

In both periods of the study, legumes had a very small share - among them were found e.g. Melilotus alba Medik., Trifolium arvense L., Vicia hirsuta (L.) Gray (Table 4 and 5). Their constancy classes and cover coefficients were slightly higher on soils with higher phosphorus contents. Only Trifolium arvense L. occurred with the greatest constancy classes in plantations on Cambisols (with a higher phosphorus content) in the first period of the study (IV constancy classes) (Table 7).

The species that accompanied energy willow crops had different reproduction strategies. It was stated that on Cambisols (with a higher phosphorus content) in both of the study periods, more species were propagated generatively (by seeds) (Table 6).
A hierarchical analysis allowed us to group the features of species occurring in Salix viminalis L. plantations. Four groups of the features of flora in Salix viminalis L. crops with similar total species coverage under similar conditions of i) $\mathrm{P}$ content in the soil and ii) plantations age have been identified (Fig. 3).

The first one consists of following features: nanophanerophytes, antropophytes, other apophytes, waterside and wetside species, woodland and shrub species. Species characterized by such features occurring more often in a lower content of phosphorous in soils, irrespectively of plantation age (Fig. 4). In this group are among others: trees and shrubs up to $2 \mathrm{~m}$ high ie. nanophanerophyte for example: Rubus caesius L., Sambucus nigra 
Fig. 3. The Ward method cluster analysis for standardized total coverage of species of the same type recorded in years 2013-2014 and 2018 on soils with two different phosphorous content
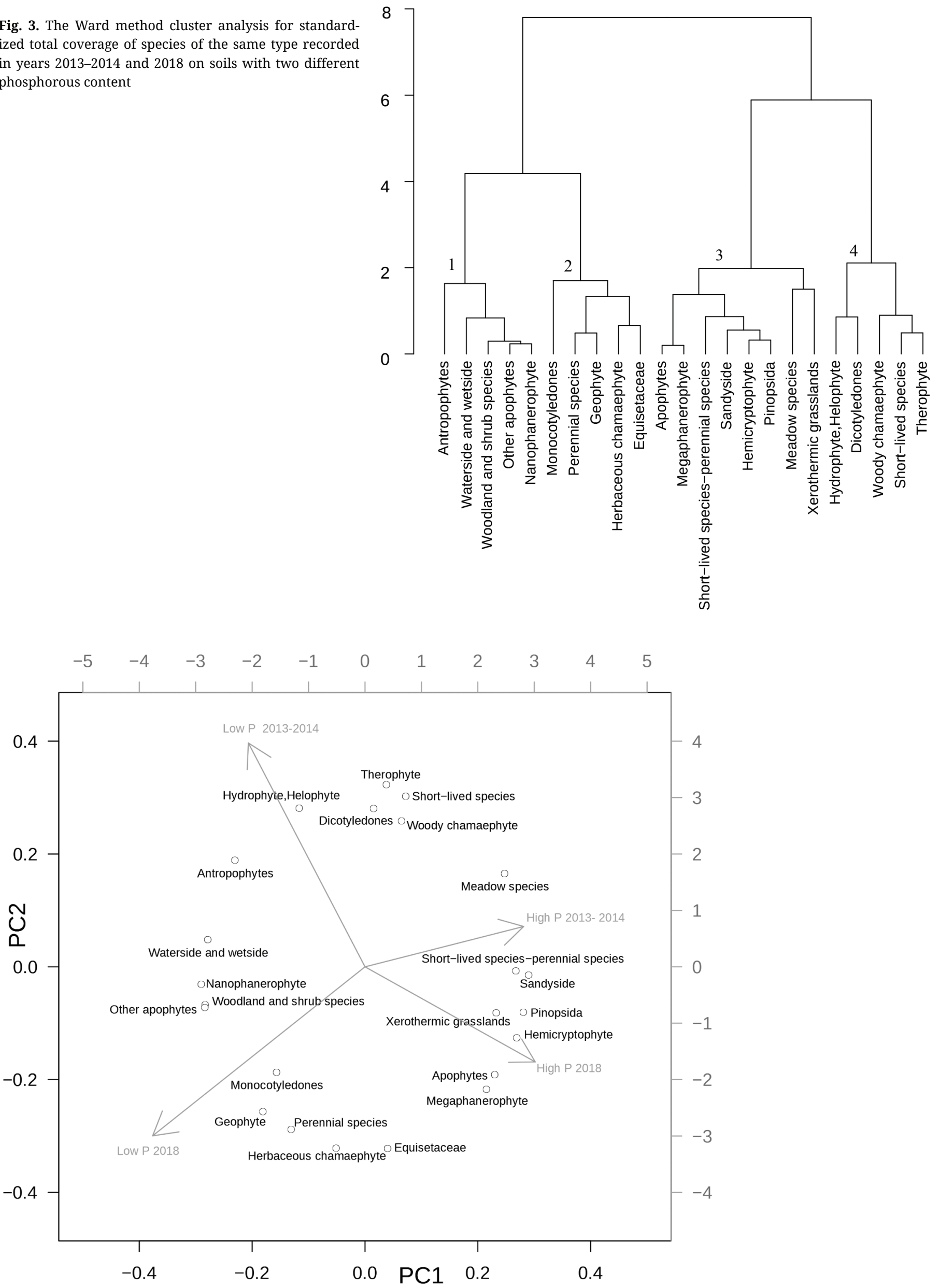

Fig. 4. The PCA biplot for standardized total coverage of species of the same type recorded in years 2013-2014 and 2018 and on soils with two different phosphorous contents. First axis retained $51 \%$ of variability and the second axis $41 \%$ of variability 
L. This two species occurred in woodland and shrubs places and reproduce vegetatively and generatively. Group 2 (Fig. 2), however, included features of species which are more common in older plantations (in 2018) regardless of the phosphorus content in the soil (Fig. 4). This group included perennial species, especially geophytes (Fig. 3, 4) - perennials, forming underground organs, with buds hidden in the soil. They occur mainly in deciduous forests, in the older willow plantations occurred, among others Glechoma hederacea L., and Calamagrostis epigejos (L.) Roth. The third group (Fig. 3) includes features of species that preferred a higher phosphorus content in soil, regardless of plantation age (Fig. 4). These were megafanerophytes and species from the Pinopisda family, e.g. Betula pendula Roth, Pinus sylvestris L. (Table 7). These two species reproduced generatively. The fourth group (Fig. 3) presents the features of species, which were more often observed (Fig. 4) in the first study period and disappeared over time. This group included shortlived species, especially therophytes - closing their life cycle in a period of one year, e.g. Galeopsis tetrahit L., Galium aparine L., These species belong to Dicotyledones (Fig. 3, 4), like the majority of crop flora.

\section{Discussion}

The flora occurring in the studied plantations of Salix viminalis L. was rich and varied. The differences in phosphorus content in the soil were reflected in species composition and the structure of the vegetation accompanying the energy willow crops. In the literature, there are no surveys about the influence of soil phosphorus content on the floristic diversity of Salix viminalis L. crops. However, this relationship has been determined, for example, in meadow communities (Janssens et al., 1998; Spychalski et al., 2010). An assessment of the effects of this nutrient on the flora composition of Salix viminalis L. plantations is difficult because its availability to plants is determined by many factors, including soil properties such as soil pH, moisture, physicochemical conditions, and parent rock. At the same time, many factors have an influence on flora, such as age of the plantation, use of the field before establishing the crop, harvest frequency, and location. These factors acting together determine the plant composition and type of plant community.

It is worth emphasizing that in the first period of our study, a higher total number of vascular plant species was found in willow plantations on Fluvisols and Phaeozems, soils with a lower available phosphorus content. Similarly, floristically richer meadow communities on soils poorer in phosphorus were stated by Kamiński and Chrzanowski (2009), whereas, Spychalski et al. (2010) recorded the highest number of species in meadow communities with $30-50 \mathrm{mg} \cdot \mathrm{kg}^{-1}$ content of available phosphorus. Also Ceulemans et al. (2014) found a negative correlation between species richness and phosphorous content in soils of European grasslands, regardless of the level of atmospheric nitrogen deposition and soil acidity. Similarly, Dobben et al. (2017) stated that the decrease in the number of species on grassland may be associated with a high phosphorus content in soil.
It should be noted that in our own research, soils with a lower phosphorus content, in the Ner river valley, in Okołowice (Fluvisols) were characterized by better water-air properties and higher agricultural and use value than soils with a higher phosphorus content (Cambisols). It also affected the development of more plant species in energy willow crops. This confirms the results of Skrajna et al. (2009), Wróbel et al. (2011) and Janicka et al. 2020 who recorded more species on wet soils than on dry ones. Whereas, irrespectively of the phosphorous content in all plantations, in the second study period, a lower number of species was found compared to the first study period. This was due to the age of Salix viminalis L. crops and smaller light supply for herbaceous plants.

The results of our study showed that the phosphorus content in the soil did not have a significant impact on the average number of species in the phytosociological relevé, which decreased with the age of energy willow crops. Whereas, Janssens et al. (1998) stated the highest number of species in the phytosociological relevé in the meadow communities growing on soils with a phosphorus content below $50-80 \mathrm{mg} \mathrm{P} \cdot \mathrm{kg}^{-1}$ soil.

Among the relatively high number of species occurring in the willow energy plantations, significant shares were grasses. However, it is difficult to distinguish taxa, classified as phosphorophilous species. Salix viminalis L. plantations are communities characteristic of forest and shrub ecosystems, forming a system composed of plants belonging to different phytosociological classes, which, as the dynamics show, visibly change over time. This is indicated by the share of species with a high cover coefficient, such as Calamagrostis epigejos (L.) Roth., Hieracium pilosella L. and Urtica dioica L. Calamagrostis epigejos (L.) Roth is a perennial species often forming extensive grasslands, occurring in shrubs, clearings, on unflooded Fluvisols and neglected meadows. Hieracium pilosella L. is found in heaths, roadsides and light pine forests, as well as in dry meadows and pastures where in greater numbers, it is undesirable due to it hindering the development of grasses. Urtica dioica $\mathrm{L}$. is associated with shrubs, clearings and ruderal sites.

The many years of willow cultivation (10-11 years) and severe light deficiency has caused a decrease in the number of species accompanying Salix viminalis L. crops over the years. Along with this, the number of perennial species has increased, regardless of the soil phosphorus content. These results confirm the results of other authors who found a domination of perennial species in older (over 3 years old) willow energy crops (Korniak et al., 2009; Baum 2012). In the studied plantations, regardless of the soil phosphorus content, woodland-shrub, meadow and hemicryptophytes dominated. This was due to the age of the plantations. The domination of such flora groups in willow energy crops confirms the results of studies obtained by AniolKwiatkowska et al. (2009) and Korniak et al. (2009).

An increase in the cover coefficient by the invasive Padus serotina (Ehrh.) Borkh. species is a negative aspect recorded in plantations and this species should be monitored in the future. The occurrence of this species in the studied crops is associated with the close proximity of forests around the plantations. In the second period of the study (2018), species from the Artemisietea vulgaris class dominated on the soils that were 
poorer in phosphorus, and species from the Molinio-Arrhenatheretea class dominated on phosphorus-rich soils (Fig. 2). In the meadow communities assessed by Kamiński and Chrzanowski (2009), meadows on soils with a higher content of phosphorus were more susceptible to flora synanthropization, which is indicated by a greater number of species from the classes: Artemisietea vulgaris and Stellarietea mediae.

Among dicotyledonous species in Salix viminalis L. plantations, there were also legumes, which, for environmental and economic reasons, are particularly important in meadow communities. Analyzing their share, depending on the soil phosphorous content, we may have found a similarity to meadow communities for which other authors found positive correlations between the soil phosphorus content and the share of legumes. A greater share of legume species in meadow communities on soils with a higher phosphorus content was noted by Spychalski et al. (2010). The lack of arable land utilization contributed to the fact that the share of legume species in Salix viminalis L. plantations. L. was small and species from different phytosociological classes (Artemisietea vulgaris, MolinioArrhenatheretea and Stellarietea mediae) dominated. Fabaceae are photophilous plants, worse light conditions can be the reason for their low share in willow plantations regardless of soils conditions. Therefore, in several and over ten years old energy willow crops, perennial species predominated, including woody-shrub and meadow apophytes (Janicka et al. 2019).

Taking into consideration the higher number of species reproducing from seeds in plantations with a higher soil phosphorus content, it is worth noting the results of research done by Fujita et al. (2013), who stated that, in phosphorous-poor environments, plants invest little in the expensive energy process of seed production and reproduce mainly vegetatively. It was found that during the formation of seeds, considerable amounts of phosphorus are transported to them from leaves and stems. Therefore, under phosphorus deficiency, plants set up less fruits and form less seeds.

\section{Conclusions}

1. The research did not clearly show the influence of soil abundance in phosphorus (available for plants) on species richness and the dynamics of flora accompanying Salix viminalis $\mathrm{L}$. Therefore, further studies in this field, extended to the forms of phosphorus in soil, are necessary.

2. The 10-11 years old Salix viminalis L. plantations developing on Fluvisol and Phaeozems (with a low content of phosphorus) have a higher number of vascular plant species than plantations on Cambisols (rich in phosphorus).

3. Regardless of soil type, with the age of the plantation the total number of species of energy willow flora has decreased, while the number of perennial species and woodland-shrub apophytes has increased.

\section{References}

Anioł-Kwiatkowska, J., 1974. Flora i zbiorowiska synantropijne Legnicy, Lubina i Polkowic. Acta Universitstis Wratislaviensis. Prace Botaniczne 229, 1-151.

Anioł-Kwiatkowska, J., Kącki, Z., Śliwiński, M., 2009. Porównanie kompozycji gatunkowej trzech upraw wierzby energetycznej. Pamiętnik Puławski 150, 19-33.

Baum, S., Weih, M., Bolte, A., 2012. Stand age characteristics and soil properties affect species composition of vascular plants in short rotation coppice plantations. BioRisk 7, 51-71. https://doi:10.3897/biorisk.7.2699.app

Braun-Blanquet, J., 1964. Pflanzensoziologie: Grundzüge der Vegetationskunde. Springer-Verlag, Wien-New York.

Ceulemans, T., et al., 2014. Soil phosphorous constrains biodiversity across European grasslands. Global Change Biology 20, 3814-3822. https://doi.org/10.1111/gcb.12650

Dobben van, H., Wieger Wamelink, G.W., Slim, P.A., Kamiński, J., Piórkowski, H., 2017. Speciest-rich grassland persist under nitrogenrich but phosphorous-limited conditions. Plant Soil 411, 451-466. https://link.springer.com/article/10.1007/s11104-016-3021-z

Dobrzański, B., Zawadzki, S., 1981. Gleboznawstwo. PWRiL, Warszawa.

Fujita, Y. et al., 2014. Low investment in sexual reproduction threatens plant adapter to phosphorus limitation. Natura 505, 82-86. https:// doi:10.1038/nature12733

Głowacka, A., Klikocka, H., Szostak, B., Narolski, B., 2017. Regulacja zachwaszczenia i sposób uprawy a dostępność fosforu dla roślin uprawnych. Polish Journal of Agronomy 28, 3-11.

IUSS Working Group WRB, 2015. World Reference Base for Soil Resources 2014, update 2015 International soil classification system for naming soils and creating legends for soil maps. World Soil Resources Reports No. 106. FAO, Rome.

Janicka, M., Kutkowska, A., Paderewski, J., 2019. Diversity of vascular flora in Salix viminalis L. crops depending on the harvest cycle. Annual Set The Environment Protection 21, 1175-1201.

Janicka M., Kutkowska, A., Paderewski, J., 2020. Diversity of vascular flora accompanying Salix viminalis L. crops depending on soil conditions, Global Ecology and Conservation, 23, e01068. https://doi.org/10.1016/ j.gecco.2020.e01068

Janssens, F., Peeters, A., Tallowin, J.R.B., Bakker, J.P, Bekker, R.M., Fillat, F., Oomes, M.J.M., 1998. Relationship between soil chemical factors and grassland. Plant and Soil 202, 69-78. https://link.springer.com/ article/10.1023/A:1004389614865

Jurga, B., Filipek, A., 2017. Wpływ wybranych praktyk rolniczych na dostępność fosforu dla roślin - przegląd piśmiennictwa. Studia i Raporty IUNG-PIB 53 (7), 55-66.

Kamiński, J., Chrzanowski, S., 2009. Zróżnicowanie florystyczne i walory przyrodnicze łąk na tle zasobności gleb torfowo-murszowych w fosfor. Woda-Środowisko-Obszary Wiejskie 9, 3 (27), 77-88.

Korniak, T., 1992. Flora segetalna północno-wschodniej Polski, jej przestrzenne zróżnicowanie i współczesne przemiany. Acta Academiae Agriculturae AC Technicae Olstenensis, Agricultura 53, Supplementum A, 1-77.

Korniak, T., Hołdyński, Cz., Wąsowicz, K., 2009. Przemiany flory chwastów upraw wierzby w północno-wschodniej Polsce. Pamiętnik Puławski 150, 159-170.

Ławniczak, A.E., 2011. Wpływ wilgotności siedliska i zasobności w składniki biogenne na bioróżnorodność flory obszarów podmokłych. Nauka Przyroda Technologie 5, 5, 1-18.

Matuszkiewicz, W., 2012. Przewodnik do oznaczania zbiorowisk roślinnych Polski. Wydawnictwo Naukowe PWN, Warszawa. 
Mirek, Z., Piękoś-Mirkowa, H., Zając, A., Zając, M., 2002. Flowering plants and pteridophytes of Poland - a checklist. [In:] Mirek, Z. (Ed), Szafer, W., Biodiversity of Poland Kraków: Institute of Botany, Polish Adacemy of Sciences, Kraków.

Mowszowicz, J., 1986. Krajowe chwasty polne i ogrodowe. PWRiL, Warszawa.

Niewiadomski, A., Tołoczko, W., 2014. Characteristics of soil cover in Poland with special attention paid to the Łódz region. Łódź University Press.

Pawłowski, B., 1972. Skład i budowa zbiorowisk roślinnych oraz metody ich badania. [In]: Szafer, W., Zarzycki K. (Ed), PWN, I, Warszawa, 237-269.

Polskie Towarzystwo Gleboznawcze, 2009. Klasyfikacja uziarnienia gleb i utworów mineralnych - PTG 2008 (Particle size distribution and textural classes of soils and mineral materials - classification of Polish Society of Soil Science 2008). Roczniki Gleboznawcze - Soil Science Annual 60(2), 5-16. (in Polish with English abstract)

Rutkowski, L., 2008. Klucz do oznaczania roślin naczyniowych Polski niżowej. 2 wyd. Wydawnictwo Naukowe PWN, Warszawa.

Sala, O.E., et al., 2000. Global biodiversity scenarios for the year 2100 . Science, 287, 1770-1774. https://DOI: 10.1126/science.287.5459.1770

Sienkiewicz-Paderewska D., Paderewski J., 2015. Habitat preferences of plant communities: New approach based on the GGE biplot analysis. Polish Journal of Ecology 63, 387-399. https://doi.org/10.3161/ 15052249PJE2015.63.3.009

Skrajna, T., Skrzyczyńska, J., Rzymowska, Z., Affek-Starczewska, A., 2009. Composition and structure of communities infesting Salix sp. in the northern part of Południowopodlaska Lowland. Pamiętnik Puławski 150, 255-264.
Sowa, R., Warcholińska, U., 1981. Flora synantropijna Sulejowa i Podklasztorza. Acta Universitatis Lodziensis Folia Botanica 1, 77-131.

Spychalski, W., Kryszak, J., Kryszak, A., 2010. Zawartość fosforu w glebach a zróżnicowanie florystyczne zbiorowisk łąkowych. Woda-Środowisko-Obszary Wiejskie 10, 4 (32), 237-247.

Systematyka Gleb Polski, 2019. Polskie Towarzystwo Gleboznawcze, Komisja Genezy Klasyfikacji i Kartografii Gleb. Wydawnictwo Uniwersytetu Przyrodniczego we Wrocławiu, Polskie Towarzystwo Gleboznawcze, Wrocław-Warszawa: 235 pp.

Szafer, W., Kulczyński, S., Pawłowski, B., 1969. Rośliny Polskie. 3 wyd. PWN, Warszawa.

Tokarska-Guzik, B., Dajdok, Z., Zając, M., Zając, A., Urbisz, A., Danielewicz, W., Hołdyński, Cz., 2012. Rośliny obcego pochodzenia w Polsce ze szczególnym uwzględnieniem gatunków inwazyjnych. Generalna Dyrekcja Ochrony Środowiska, Warszawa.

Wróbel, M., Wróbel, J., Gregorczyk, A., 2011. Floristic and community diversity of weed vegetation in willow short-rotation coppices in different soil-habitat conditions. Polish Journal of Ecology 59 (2), 289-296.

Zając, A., 1979. Pochodzenie archeofitów występujących w Polsce. Rozprawa habilitacyjna 29, Wyd. UJ, Kraków.

Zając, E.U., Zając, A., 1975. Lista archeofitów występujących w Polsce. Zeszyty Naukowe UJ Prace Botaniczne 395 (3), 7-16.

Zając, M., Zajac, A., 1992. A tentative list of segetal and ruderal apophytes in Poland. Zeszyty Naukowe UJ, Prace Botaniczne 24, 7-23.

website 1: http://www.geoportal.lodzkie.pl (accessed 24.01.2020)

website 2: https://www.R-project.org/. Core Team (2019). R: A language and environment for statistical computing. R Foundation for Statistical Computing, Vienna, Austria. URL https://www.R-project.org/.)

\section{Słowa kluczowe}

Salix viminalis $\mathrm{L}$. Uprawy energetyczne Flora naczyniowa Dynamika flory Fosfor przyswajalny

\section{Charakterystyka flory upraw Salix viminalis L. założonych na glebach o różnej zasobności $w$ fosfor}

\section{Streszczenie}

Celem badań było określenie wpływu stopnia zasobności gleb w fosfor na różnorodność i dynamikę flory towarzyszącej uprawom wierzby energetycznej Salix viminalis L. w dwóch przedziałach czasowych. Badania przeprowadzono w latach 2013-2014 na plantacjach 5-7-letnich i w roku 2018 na plantacjach 10-11-letnich, w trzech miejscowościach województwa łódzkiego. Oceniono 6 plantacji założonych w latach 2006-2008 na dwóch grupach gleb: 1) o bardzo niskiej i niskiej zawartości fosforu oraz 2) o średniej i wysokiej zawartości fosforu. Przed założeniem plantacji grunty były odłogowane. W trakcie badań nie były nawożone. Wierzbę zbierano systematycznie co 2-3 lata. Roślinność towarzyszącą wierzbie oceniono na podstawie analizy 40 zdjęć fitosocjologicznych wykonanych metodą Brauna-Blanqueta. Wyniki opracowano statystycznie za pomoca analizy składowych głównych (PCA) oraz analizy skupień. W celu pogrupowania silnie powiązanych zmiennych zastosowano odległość euklidesową i metodę Warda. Flora upraw wierzby energetycznej założonych na glebach o różnej zawartości fosforu różniła się ogólną liczbą gatunków roślin naczyniowych. Na plantacjach 5-7-letnich rozwijających się na glebach o niższej zawartości fosforu stwierdzono występowanie 71 taksonów, natomiast na glebach o wyższej zawartości fosforu ich liczba wynosiła 56. W 10-11-letnich uprawach Salix viminalis L. liczba gatunków była mniejsza i wynosiła odpowiednio 35 i 42. We florze obu grup plantacji, niezależnie od okresu badań, dominowały gatunki wieloletnie, dwuliścienne (74\%-83\%), hemikryptofity, apofity leśno-zaroślowe i łąkowe. Najwięcej gatunków należało do klas: Artemisietea vulgaris, Molinio-Arrhenatheretea i Stellarietea mediae. Analiza dynamiki flory wykazała zmniejszanie się ogólnej liczby gatunków wraz z wiekiem plantacji. W obu grupach plantacji wzrastał udział gatunków wieloletnich, apofitów leśnych i zaroślowych. W uprawach rosnących na glebach o niższej zawartości fosforu w drugim okresie badań dominowały gatunki z klasy Artemisietea vulgaris, a na bogatszych w fosfor - gatunki z klasy Molinio-Arrhenatheretea, duży udział stanowiły także gatunki nie zaliczone do żadnej z klas fitosocjologicznych. W obu okresach badań niewielki udział miały rośliny bobowate, których występowanie i pokrycie było nieznacznie większe na plantacjach bogatszych w fosfor. 